\title{
Child Neurology: Arterial ischemic stroke in a 12-year-old patient with cardiac myxomas
}

Elizabeth Coffee, MD, Neal Sankhla, MD, Rachel Bass, DO, Leon Dure, MD, and Salman Rashid, MD

Neurology ${ }^{\circledR}$ 2020;94:e1103-e1106. doi:10.1212/WNL.0000000000009060
Correspondence

Dr. Coffee

eacoffee@uabmc.edu

Arterial ischemic strokes (AIS) are the most frequent neurologic sequela encountered in patients with cardiac myxomas. Although most of these AIS are thrombotic in nature, occasionally embolized tumor fragments may be responsible for the ischemic damage. ${ }^{1}$ Most patients with cardiac myxoma are women between the third and the sixth decade of life, who present with one or more symptoms of the classic triad (hemodynamic instability due to intracardiac obstruction, systemic embolization, and constitutional symptoms). ${ }^{1}$ Carney complex is an inherited disorder characterized by myxomas that often present earlier in life. We present a 12-year-old girl who developed a pediatric AIS (PAIS) due to the direct embolization of cardiac myxomatous tissue fragments in the setting of Carney complex. We discuss the clinical presentation, case-specific differential diagnosis, and workup, followed by epidemiology, pathophysiology, treatment, and prognosis of AIS resulting from cardiac myxomas.

\section{Case report}

A 12-year-old girl presented with sudden onset of expressive aphasia, disorientation, and agitation for 1 hour. Her initial examination did not reveal overt motor weakness. CT of the head was unremarkable. Within the next 3 hours, she developed a right facial droop and right hemiparesis, and was noted to have pulseless lower extremities. An urgent MRI/magnetic resonance angiogram (MRA) of the brain was obtained 5 hours after presentation and showed diffusion restriction in the left basal ganglia (figure, $\mathrm{A}$ and $\mathrm{B}$ ) along with a complete obstruction of flow of the M1 segment of the left middle cerebral artery (figure, C). Mechanical thrombectomy achieved complete perfusion. The retrieved specimen had yellow discoloration and a gelatinous consistency. During the procedure, obstructive lesions of distal abdominal aorta extending into bilateral iliac and popliteal arteries were visualized, prompting further intervention (figure, D). Postoperatively, the patient was started on continuous heparin infusion due to concerns for a systemic prothrombotic state and she was transferred to our hospital for higher level of care.

Upon arrival, the patient's neurologic examination revealed mild language dysfluency with normal comprehension, naming, and repetition. She had right upper motor neuron-type facial droop, right hemiparesis, and decreased sensation to pinprick in her right lower extremity. Her extremity pulses were restored. Because of concern for a large vessel vasculitis, high-dose IV corticosteroids were initiated. Transthoracic echocardiography on the next day revealed a $2 \times$ $2.7-\mathrm{cm}$ left atrial pedunculated mass, which was further visualized on cardiac MRI (figure, E). Treatment with IV steroids was therefore discontinued. Pathologic evaluation of the retrieved specimen was consistent with myxomatous tissue. Surveillance CT head obtained 48 hours after presentation revealed punctate hemorrhages within the infarct, which led to multidisciplinary discussions regarding the use of heparin. With parental consent, heparin infusion was maintained for an attenuated anti-Xa goal of $0.3-0.5 \mathrm{IU} / \mathrm{mL}$ (customary anticoagulation goal: $0.3-0.7 \mathrm{IU} / \mathrm{mL}$ ). Surgical removal of the left atrial as well as right-sided cardiac masses, which were identified subsequently on imaging, was achieved without complications 10 days after the initial presentation.

From the Department of Neurology (E.C., L.D., S.R.) and Department of Pediatrics (N.S., R.B., L.D., S.R.), Division of Pediatric Neurology, School of Medicine, University of Alabama at Birmingham.

Go to Neurology.org/N for full disclosures. Funding information and disclosures deemed relevant by the authors, if any, are provided at the end of the article. 


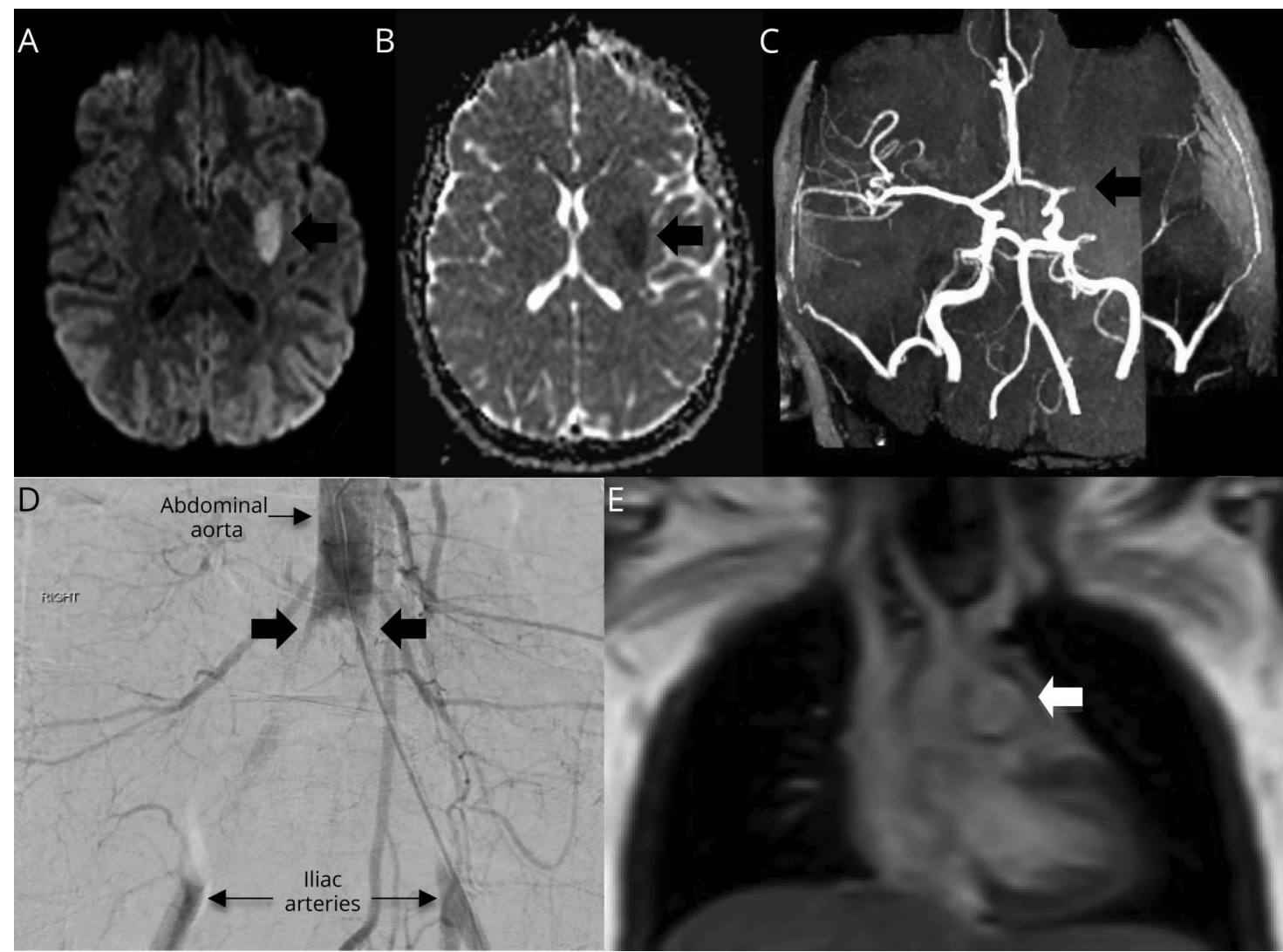

(A) Diffusion-weighted B1000 MRI brain (axial image) displays diffusion restriction within the left basal ganglia. (B) Apparent diffusion coefficient MRI brain (axial image) demonstrates correlate to the diffusion-weighted scan. (C) Magnetic resonance angiogram brain displays abrupt cutoff along the M1 segment of the left middle cerebral artery. (D) Angiogram demonstrates abdominal aortic filling defect extending to bilateral common iliac arteries resulting in no visualization of these arteries (large black arrows). Distal filling of the internal and external iliac arteries is seen (small black arrows). (E) Cardiac MRI demonstrates intracardiac mass.

Given the early radiologic identification and microscopic confirmation of the suspected etiology, a targeted laboratory workup was performed that was unremarkable for a coexisting prothrombotic disorder. Further history subsequently revealed that the patient's mother was previously diagnosed with a nerve sheath myxoma, and her sister was found to have a benign cutaneous tumor. Genetic testing revealed PRKAR1A mutation, which was consistent with Carney complex. Four-week follow-up with conventional cerebral angiogram as well as annual transthoracic echocardiography and neurovascular imaging to screen for aneurysm formation was planned.

\section{Differential diagnosis and workup}

Common differential diagnosis of the risk factors and etiology of PAIS may be broadly classified into arteriopathies, cardiac disorders, inherited or acquired thrombophilia, sickle cell disease, malignancy, inborn errors of metabolism, and rheumatologic diseases including systemic vasculitides. ${ }^{2}$ There are frequently multiple risk factors present in a single patient. In patients who present with symptoms and signs of stroke with evidence of extensive obstructive lesions of large vessels, a working differential of arterial thrombophilias, large vessel vasculitis, malignancy, and cardioembolic etiologies is reasonable. In this clinical context, it is not unreasonable to evaluate for the benefit of systemic steroid therapy. However, before initiating systemic therapy, it is important to note that several published cases have reported atrial myxomas being initially misdiagnosed as vasculitis, including Takayasu arteritis, polyarteritis nodosa, and giant cell arteritis. ${ }^{3}$ One of these case reports also mentions that a prolonged course of high-dose corticosteroids may predispose myxomas and the surrounding cardiac tissue to endocarditis. Because of such implications of a presumptive treatment, it was proposed that patients with suspected diagnosis of vasculitis should undergo an echocardiography to rule out myxoma before initiating treatment. ${ }^{3}$ In addition to echocardiography and telemetry monitoring, the PAIS workup at our institution is outlined in the table.

\section{Epidemiology and pathophysiology}

The incidence of cardiac tumors causing PAIS is unknown, but the pathophysiology of these tumors leading to cerebral embolization has been studied. Most primary cardiac tumors are benign, with myxomas being the most common type. ${ }^{4}$ The majority of cardiac myxomas are sporadic; however, a familial pattern has been described in Carney complex, which is an autosomal-dominant syndrome with cardiac myxomas, 
Table Pediatric arterial ischemic stroke laboratory workup

\begin{tabular}{ll}
\hline Routine serum studies & $\begin{array}{l}\text { Autoimmune antibody } \\
\text { testing }\end{array}$ \\
\hline C-reactive protein & $\begin{array}{l}\text { Antineutrophil } \\
\text { cytoplasmic antibodies }\end{array}$ \\
\hline Erythrocyte sedimentation rate & SSA/SSB antibodies \\
\hline Lipoprotein(a) levels & Smith antibodies \\
\hline Factor VII levels & Scl-70 antibodies \\
\hline von Willebrand factor antigen testing & $\begin{array}{l}\text { Antiphospholipid } \\
\text { antibodies }\end{array}$ \\
\hline
\end{tabular}

Protein $\mathrm{C}$ and $\mathrm{S}$ testing

Antithrombin III activity

Activated protein C resistance assay

Homocysteine levels

HIV screen

Rapid plasma reagin

Varicella titers

Prothrombin and methylenetetrahydrofolate reductase genetic testing

extracardiac myxomas, cutaneous pigmentation, endocrine abnormalities, and other tumors, and accounts for about $5 \%-10 \%$ of cardiac myxomas. ${ }^{4,5}$ The histologic origin of these tumors is uncertain; however, they are thought to develop from multipotent mesenchymal stem cells. Macroscopically, myxomatous tissue is gelatinous and may have a polypoid or papillary appearance. ${ }^{4}$ Due to their fragile nature along with higher potential for erosion and embolization, papillary myxomas are more likely to lead to embolism than polypoid tumor. ${ }^{4,5}$ Systemic embolization from cardiac myxoma is seen in up to $50 \%$ of cases. This may involve cerebral vasculature in up to half of these cases, with extracerebral involvement that includes retinal, lower extremity, renal, coronary, and occasionally abdominal aortic vessels in the remainder. ${ }^{5}$ Embolization may result from tissue fragmentation, tumor detachment, or spread of overlying thrombi/vegetations from the tumor surface. In addition to embolization limited to arterial lumen, metastatic extracardiac lesions have been reported in various tissues including brain parenchyma and vessel wall. ${ }^{5}$ The incidence of these metastasis is unknown.

\section{Treatment and prognosis}

Treatment of cardiac myxoma and its neurologic sequela, including AIS, fusiform aneurysms, cavernous malformations, and myxomatous metastasis, begins with resection of the primary mass (American Heart Association, class 1C guideline). ${ }^{6}$ Recurrence rates of myxomas in patients with Carney complex (as opposed to sporadic myxomas) is up to $25 \%$, with a recommendation of lifetime annual echocardiography for the patient and familial screening. ${ }^{7}$ The most common neurologic sequel of cardiac myxoma is AIS, of which the management in pediatric patients is largely extrapolated from adult studies. Whereas formal guidelines do not recommend the routine use of IV recombinant tissue plasminogen activator outside of research protocols in pediatric patients, thrombectomy has been reported to be successful in PAIS secondary to occlusive embolism from cardiac myxoma and may be considered based on institutional experience and the individual clinical picture. ${ }^{8}$ For secondary prevention of PAIS due to a cardioembolic source, anticoagulation with lowmolecular-weight heparin or warfarin is recommended if the risk of recurrence remains high. ${ }^{6}$ Otherwise, in the absence of sickle cell disease, secondary prevention of PAIS with antiplatelet therapy may be considered, though the optimal length of treatment is unknown. ${ }^{6}$

In patients with cardiac myxomas, intracerebral myxomatous aneurysms may be found on initial workup or as a delayed manifestation reported up to 25 years after tumor resection. ${ }^{9}$ Digital subtraction angiography is preferred for diagnosis given limitations of MRA and CT angiogram in detection of myxomatous aneurysms. ${ }^{10}$ Whereas endovascular coiling, surgical management, and embolization have all been reported, treatments are limited given fusiform morphology and peripheral cerebral vascular predilection. ${ }^{10}$ It is generally accepted to maintain antiplatelet therapy, though recurrent AIS is often reported in the presence of antiplatelet agents started at initial presentation. In patients who develop parenchymal metastasis, a combination of surgical resection, radiation, and chemotherapy leading to complete remission has been reported, and theoretically could be considered in aneurysm prevention or treatment as well. ${ }^{9}$

Prognosis of PAIS from all causes remains suboptimal. Studies show that more than $50 \%-80 \%$ of children will experience long-term neurologic deficits, ${ }^{2}$ and up to $14 \%$ will experience recurrent stroke. ${ }^{6}$ Echocardiography is an important diagnostic test with treatment and prognostic implications in patients with AIS who present with signs and symptoms suggestive of large vessel vasculitis. In the absence of tissue diagnosis, patients may be misdiagnosed with diseases like systemic vasculitis, collagen vascular disease, infective endocarditis, or rheumatic heart disease. ${ }^{4,5}$ In the subpopulation of PAIS due to cardiac myxoma with or without aneurysm formation, optimal management or prognosis remains unknown. Unique patient characteristics may pose further management challenges. In such cases, a multidisciplinary approach with transparent discussions with the patient and his or her parents is necessary to determine the treatment course.

\section{Study funding}

No targeted funding reported.

\section{Disclosure}

The authors report no disclosures relevant to the manuscript. Go to Neurology.org/N for full disclosures. 


\section{Appendix Authors}

\begin{tabular}{llll}
\hline Name & Location & Role & Contribution \\
\hline $\begin{array}{l}\text { Elizabeth } \\
\text { Coffee, } \\
\text { MD }\end{array}$ & $\begin{array}{l}\text { University of } \\
\text { Alabama at } \\
\text { Birmingham }\end{array}$ & Author & $\begin{array}{l}\text { Drafting and revising the } \\
\text { manuscript, study concept and } \\
\text { design }\end{array}$ \\
\hline $\begin{array}{l}\text { Neal } \\
\text { Sankhla, } \\
\text { MD }\end{array}$ & $\begin{array}{l}\text { University of } \\
\text { Alabama at } \\
\text { Birmingham }\end{array}$ & Author & $\begin{array}{l}\text { Revising the manuscript, } \\
\text { analysis and interpretation of } \\
\text { data }\end{array}$ \\
\hline $\begin{array}{l}\text { Rachel } \\
\text { Bass, Do }\end{array}$ & $\begin{array}{l}\text { University of } \\
\text { Alabama at } \\
\text { Birmingham }\end{array}$ & Author & $\begin{array}{l}\text { Revising the manuscript, } \\
\text { analysis and interpretation of } \\
\text { data }\end{array}$ \\
$\begin{array}{l}\text { Leon } \\
\text { Dure, MD }\end{array}$ & $\begin{array}{l}\text { University of } \\
\text { Alabama at } \\
\text { Birmingham }\end{array}$ & Author & $\begin{array}{l}\text { Revising the manuscript, } \\
\text { analysis and interpretation of } \\
\text { data }\end{array}$ \\
$\begin{array}{l}\text { Salman } \\
\text { Rashid, } \\
\text { MD }\end{array}$ & $\begin{array}{l}\text { University of } \\
\text { Alabama at }\end{array}$ & Author & $\begin{array}{l}\text { Drafting and revising the } \\
\text { manuscript, analysis and } \\
\text { interpretation of data }\end{array}$ \\
\hline
\end{tabular}

\section{References}

1. Lee VH, Connolly HM, Brown RD. Central nervous system manifestations of cardiac myxoma. Arch Neurol 2007;64:1115-1120.

2. Felling RJ, Sun LR, Maxwell EC, Goldenberg N, Bernard T. Pediatric arterial ischemic stroke: epidemiology, risk factors, and management. Blood Cell Mol Dis 2017;67:23-33.

3. Fung K, Edmondson S, Wald DS. Atrial myxoma masquerading as Takayasu's arteritis. JRSM Open 2014;5:2054270414550977.

4. Singhal P, Luk A, Rao V, Butany J. Molecular basis of cardiac myxomas. Int J Mol Sci 2014; 15:1315-1337.

5. Gosev I, Paić F, Durić Z, et al. Cardiac myxoma the great imitators: comprehensive histopathological and molecular approach. Int J Cardiol 2013;164:7-20.

6. Roach ES, Golomb MR, Adams R, et al. Management of stroke in infants and children: a scientific statement from a special writing group of the American Heart Association Stroke Council and the Council on Cardiovascular Disease in the Young. Stroke 2008; 39:2644-2691.

7. O'Rourke F, Dean N, Mouradian MS, Akhtar N, Shuaib A. Atrial myxoma as a cause of stroke: case report and discussion. CMAJ 2003;169:1049-1051.

8. Vega R, Chan J, Anene-Maidoh T, Grimes M, Reavey-Cantwell J. Mechanical thrombectomy for pediatric stroke arising from an atrial myxoma: case report. J Neurosurg Pediatr 2015;15:301-305.

9. Sabolek M, Bachus-Banaschak K, Bachus R, Arnold G, Storch A. Multiple cerebral aneurysms as delayed complication of left cardiac myxoma: a case report and review. Acta Neurol Scand 2005;111:345-350

10. Gupta MM, Agrawal N. Oncotic cerebral aneurysms in a case of left atrial myxoma, role of imaging in diagnostics and treatment. Pol J Radiol 2015;80:490-495. 


\section{Neurology}

\section{Child Neurology: Arterial ischemic stroke in a 12-year-old patient with cardiac myxomas}

Elizabeth Coffee, Neal Sankhla, Rachel Bass, et al.

Neurology 2020;94;e1103-e1106 Published Online before print February 18, 2020

DOI 10.1212/WNL.0000000000009060

This information is current as of February 18, 2020

\section{Updated Information \&} Services

\section{References}

Subspecialty Collections

\section{Permissions \& Licensing}

\section{Reprints}

including high resolution figures, can be found at: http://n.neurology.org/content/94/10/e1103.full

This article cites 10 articles, 2 of which you can access for free at: http://n.neurology.org/content/94/10/e1103.full\#ref-list-1

This article, along with others on similar topics, appears in the following collection(s):

\section{All Pediatric}

http://n.neurology.org/cgi/collection/all_pediatric

Cardiac

http://n.neurology.org/cgi/collection/cardiac

\section{Childhood stroke}

http://n.neurology.org/cgi/collection/childhood_stroke

Information about reproducing this article in parts (figures,tables) or in its entirety can be found online at:

http://www.neurology.org/about/about_the_journal\#permissions

Information about ordering reprints can be found online:

http://n.neurology.org/subscribers/advertise

Neurology ${ }^{\circledR}$ is the official journal of the American Academy of Neurology. Published continuously since 1951, it is now a weekly with 48 issues per year. Copyright (C 2020 American Academy of Neurology. All rights reserved. Print ISSN: 0028-3878. Online ISSN: 1526-632X.

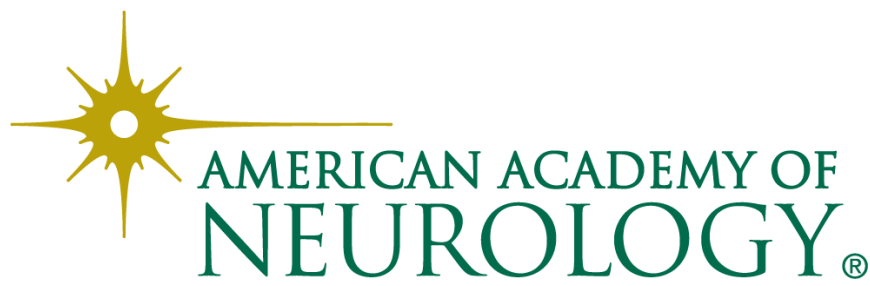

